\title{
Ses Dalgalarının Tarımsal Ürünlerin Muhafazası ve Bitki Gelişimi Üzerine Etkileri
}

\author{
Murat DikiLiTAŞ ${ }^{1 *}$, Vehbi BALAK ${ }^{2}$, Sema KARAKAŞ ${ }^{3}$ \\ ${ }^{1}$ Harran Üniversitesi Ziraat Fakültesi Bitki Koruma Bölümü, Şanlıurfa \\ ${ }^{2}$ Harran Üniversitesi Mühendislik Fakültesi Makine Mühendisliği Bölümü, Şanlıurfa \\ ${ }^{3}$ Harran Üniversitesi Ziraat Fakültesi Toprak ve Bitki Besleme Bölümü, Şanlıurfa \\ *Sorumlu Yazar: m.dikilitas@gmail.com
}

Öz

Müzik ya da sesin hayatımızı veya duygularımızı etkilediği yadsınamaz bir gerçektir. Şimdiye kadar ses dalgaları ile yapılan çalışmaların büyük çoğunluğu hücreden ziyade organ veya organizmaları konu almıştır. Ses dalgaları ile yapılan çalışmalar bundan 60-70 yıl öncesine dayanmasına rağmen hücre üzerindeki etkisi son yıllarda anlaşılmaya başlanmıştır. Ses dalgalarının duyulabilen veya ultrasonik dalgalar olarak kullanıldıklarında organizmalar üzerinde doz, frekans ve süreye bağlı olarak olumlu ve olumsuz etkileri mevcuttur. Kimi dalgalar organizmalar üzerinde büyüme ve gelişimi teşvik ederken kimi dalgalar ise içinden geçtiği ortamda fiziksel ve kimyasal değişiklik yapabilecek potansiyele sahiptirler. Bu derlemede, çeşitli frekans, yoğunluk ve sürelerde tatbik edilen ses dalgalarının mekanizması, ürünlerin muhafazası ve bitki gelişimi üzerine etkileri ele alınmıştır.

Anahtar Kelimeler: Ses dalgası, Desibel, Frekans, Patojen, Meyve

\section{Effects of Sound Waves on Preserving Agricultural Products and Plant Development}

\begin{abstract}
Music or sound inevitably affects our emotion or feelings. Majority of studies carried out so far with sound has subjected the organs or organisms rather than the cell. Although the studies with sound extended 60-70 years before, the effect on cell has been recognized recently. Positive or negative effects of sound exist on organisms when applied as audible or ultrasonic waves depending on the dose, frequency and time. Some waves encourage the growth and development of organisms while the others have potential to modify the chemical and physical structures when passed through the organisms. In this review, the effect of sound waves applied at various frequencies, doses and time periods on agricultural products, crop protection and plant development strategies were evaluated.
\end{abstract}

Keywords: Sound waves, Desibel, Frequency, Pathogen, Fruit

\section{Giriş}

Ses enerjisi; gaz, sıvı veya katı ortamlardan geçerken etrafta bulunan moleküller tarafından absorbe edilir, absorbe edilen enerji eğer yüksek yoğunluğa sahip ise içinden geçtiği ortamda form değişikliği yapabilecek güce erişmiş olur. Ses dalgası ile ilgili çalışmalar çok çeşitli olup farklı frekans, süre ve güç kullanımını içine almıştır. Bazı çalışmalar frekans ve gücün organizmalar üzerinde olumlu etkilerini konu alırken bazıları ise ses dalgasının olumsuz etkilerini incelemiştir. Özellikle, ses dalgalarının mikroorganizmalar ve ürün muhafazası üzerindeki etkileri büyük önem kazanmıştır. Ses dalgalarının özellikleri göz önüne alındığında yüksek frekansların 
mikroorganizmaları daha hızlı ve etkin bir şekilde kontrol ettiği görülmüş, bundan dolayı ultrases dalgalarının kullanımı ile mikrobiyal canlıların üreme ve yayılma hızının azaltılarak yiyeceklerin bozulmasının önüne geçilmesi hedeflenmiştir.

Ses dalgası ile ilgili çalışmalar geçmişte $50^{\prime}$ li yıllara kadar uzanmasına rağmen, son yıllarda ziraat ve tıp alanında yapılan çalışmalar ile popülerlik kazanmıştır. Özellikle, 2006 yılı ve sonrasında yapılan çalışmalar, bu alanda ilerlemenin ne kadar hızlı ve yaygın olduğunu gözler önüne sermiştir. Ses dalgası ile yapılan çalışmaların pratiğe ve teknolojiye aktarılmasındaki kolaylık ve çevre dostu oluşu, dolayısı ile kimyasal madde kullanımını daha aşağılara çekmesi, bu teknolojinin hızlı gelişmesinde nemli etkenler olmuştur. Kullanılan teknolojinin sürekli gelişmesi, modifikasyonu ve kullanım alanlarının genişlemesi bu teknolojinin güncelliğinin korunmasında önemli rol oynamıştır. Bundan dolayı, ses dalgası ile yapılan çalışmalar uzun bir geçmişe sahip olmasına rağmen yeni teknoloji olarak adlandırılmıştır.

$\mathrm{Bu}$ derlemede, ses dalgalarının ürünlerin muhafazasında ve bitki gelişiminde gösterdiği başarılar ele alınmış ve ses dalgalarının mekanizmaları incelenmiştir.

\section{Ses dalgası ve etki mekanizması:}

Mekanik dalgalar çevremizde yaygın olarak maruz kaldığımı fiziksel etmenlerdir. Bunlar, ses, ışık ve su dalgaları olarak etrafımızda bulunmaktadırlar. Özellikle, ses dalgaları ile tarımsal alanlarda hasat öncesi ve sonrası ürün kayıplarının önüne geçilmesi, ürün ve kalite arttırımı gibi gıda sektörüne katkıda bulunulacak alanlarda kullanılması konunun önemini arttırmıştır.

Ses dalgası 3 ana spektrumda incelenmiştir. Bunlar; frekansı (titreşim) 20
$\mathrm{Hz}$ den küçük olanlar "infrasound", $20 \mathrm{~Hz}-20$ $\mathrm{kHz}$ arası olanlar "duyulabilen ses", ve $20 \mathrm{kHz}$ den büyük olanlar ise "ultrasound" yani ultrases dalgası olarak adlandırılmışlardır. Ultrases dalgası ise (20 kHz-10 MHz) ikiye ayrılmıştır. Bunlar, düşük frekanslı ultrases (20 kHz-1 MHz) ve yüksek frekanslı ultrases (1 $\mathrm{MHz}$ den büyük olanlar) dalgaları olarak adlandırılmışlardır. Ultrases dalgası da infrasound gibi insan kulağı tarafından duyulamayan frekansları içine alan ses dalgasıdır (Dolatowski ve ark., 2007).

Ultrases dalgası kullanılan enerji bakımından da sınıflandırımaya tabi tutulmuştur. Ultrases dalgaları, ses gücü (W), ses yoğunluğu (W $\mathrm{m}^{-2}$ ) ve ses enerji yoğunluğu $\left(\mathrm{W} \mathrm{s}^{-1} \mathrm{~m}^{-3}\right)$ olarak farklı şekillerde ifade edilmişlerdir (Knorr ve ark., 2004). Buna göre ultrases dalgası uygulamaları düşük enerjili ve yüksek enerjili olmak üzere ikiye ayrımıştır (Kentish ve Ashokkumar, 2011). Düşük enerji grubu, $100-1000 \mathrm{kHz}$ arasında frekansa, ve $1 \mathrm{~W} \mathrm{~m}^{-2}$ den düşük ses yoğunluğuna, yüksek enerji grubu ise 20-100 $\mathrm{kHz}$ arasında frekansa ve $1 \mathrm{~W} \mathrm{~m}^{-2}$ den yüksek ses yoğunluğuna sahiptirler.

Düşük enerjili ses dalgaları, içinden geçtiği materyalin fiziksel ve kimyasal yapısında değişiklik yapmayan dalgalardır. Gıdalar üzerinde yapıyı bozucu etki göstermez, yiyeceklerin yapısı ve fizikokimyasını aydınlatmakta kullanılırlar (Leadley ve Williams, 2006). Ayrıca, tıp ve endüstriyel alanlarda görüntüleme amaçları için kullanılmaktadırlar (Kentish ve Ashokkumar, 2011).

Yüksek enerjili ultrases dalgası ise canlı ve cansız organizmalar üzerinde fiziksel, mekaniksel ve kimyasal etkiler bırakarak fiziksel bozulmayı arttırdığı gibi kimyasal reaksiyonları da arttırırlar (Golmohamadi ve ark., 2013). Güçlü ultrases dalgaları biyolojik 
çalışmalarda en yaygın kullanılan ses dalgalarıdır (Piyasena ve ark., 2003).

Ultrases dalgası sıvılara uygulandığı zaman (sonikasyon), sıvı içinde derinlemesine dalgalar oluşturur ve bu dalgalar katı bir cisme çarptıklarında onların etrafında sıkıştırma ve genişleme bölgesi meydana getirerek bir girdap ya da kavitasyon adı verilen bir yapı oluştururlar. Kavitasyon yani oyuk denen bu yapılar hava kabarcıklarının oluşumu, büyümesi ve çökmesi sonucu oluşmaktadır. Sıvı içinde oluşan kavitasyon stabil ve non stabil olarak ikiye ayrilır. Stabil kavitasyon düşük yoğunluklu ultrases dalgası, geçici kavitasyon ise yüksek yoğunluklu ultrases dalgası ile elde edilir. Mikro hava kabarcıklar içinde oluşan gaz patlayarak yüksek sıcaklık ve basınca sahip şok dalgası oluşturur. Patlama sırasında teorik olarak $5500 \mathrm{~K}$ lik bir Isı açığa çıkar ve $100 \mathrm{MPa}$ gücünde yani $1000 \mathrm{~atm}$ gücünde bir basınç oluşur ki bu hücre içi ve dışında bulunan sıvı içinde serbest radikallerin oluşmasını sağlar (Fellows, 2000). Zincirleme şekilde oluşan bu durum negatif basınç oluşturarak mikroorganizmaların inaktive edilmesini kolaylaştırır (Valero ve ark., 2007). Bu kabarcıklar, meyve ve sebze gibi gıdaların üzerinde bulunan partikülleri koparmakta ve onların membran yapısını bozmakta oldukça başarılıdırlar. Mekanizma olarak ultrases dalgası mikroorganizmaların oluşturduğu film tabakasını parçalayacak güce de sahiptir. Yeryüzünde deniz seviyesinde oluşan atmosfer basıncınından çok daha fazla bir atmosfer basıncının açığa çıktığı düşünülürse, yüksek basınç ve enerji ortamında bulunan patojen veya patojen olmayan tüm organizmaların inaktive edilmesi mümkündür. Çünkü açığa çıkan enerji ile solüsyon içinde bulunan bakteri ve fungal mikroorganizmaların hücre çeperleri bu seviyede bir basınca direnç gösteremezler. Ultrases dalgasını tolere edemeyen mikroorganizmaların direnç kazanımı da söz konusu olmadığından dayanıklı patojen ırklarının önüne geçilmesi mümkün olabilecektir. Yukarıda bahsedilen fiziksel mekanizma dışında en önemli mekanizma kimyasal etki mekanizmasıdır. Bu mekanizma hücre membranlarının incelmesi, bölgesel ısınma ve serbest radikallerin oluşumu ile izah edilmiştir (Fellows, 2000). Örneğin, 20 kHz frekasında bir ultrasonik ses dalgası, mikroorganizmaların hücre duvarlarında hidroksil radikallerinin sentezini arttırarak inaktivasyonunu sağlamıştır (Kadkhodaee ve Povey, 2008; Weiss ve ark., 2011). Yine kavitasyon sırasında hidrojen atomları hidroksil radikalleri ile birleşerek $\mathrm{H}_{2} \mathrm{O}_{2}$ oluşturur ki bu da hücre duvarına ekstra bir zarar oluşturmaktadır (Lee ve Feng, 2011). Bu aşamada ortama ilave edilen kimyasallar ikincil reaksiyonlar oluşturarak serbest radikal oluşumuna ayrıca katkıda bulunurlar. Dahası, hidroksil radikalleri DNA zincirinin omurgası olan şeker-fosfat kalıbı ile reaksiyona girerek fosfat-ester bağlarının ayrılmasına yol açarak DNA'nın tek ve çift sarmal yapısının kırılmasına neden olurlar (Dikilitas ve ark., 2015). Bu teknoloji yeni ve uygulanabilir teknoloji olmasına ragmen geniş alan ve hacimler için hala geliştirilmeye muhtaç durumdadır.

\section{Ultrases dalgasının oluşturulması:}

Bir ultrases dalgası oluşturmak için öncelikle bir elektrik kaynağı, transducer ve coupler/emitter'e gerek vardır (Mothibe ve ark., 2011). Elektrik kaynağı, ultrases dalgası için gerekli olan enerjiyi üretirken, transducerler elektrik enerjisini istenilen frekansta mekanik tireşime çevirirler ve basınç oluştururlar (Bermudez-Aguirre ve ark., 2011). Coupler/emitter ise aynı 
zamanda reaktör olarak ya da ultrases hücresi olarak da adlandırılır, ultrases dalgasının transducer'den SIVI ortama transferinde görev alır (Leadley ve Williams, 2006). Bu tür cihazlar karıştırma ve homojenizasyon işlemi için kullanılmaktadırlar. Ses dalgasının mekanizması ve bu alanda kullanılan yöntem Şekil 1a ve b'de sunulmuştur.

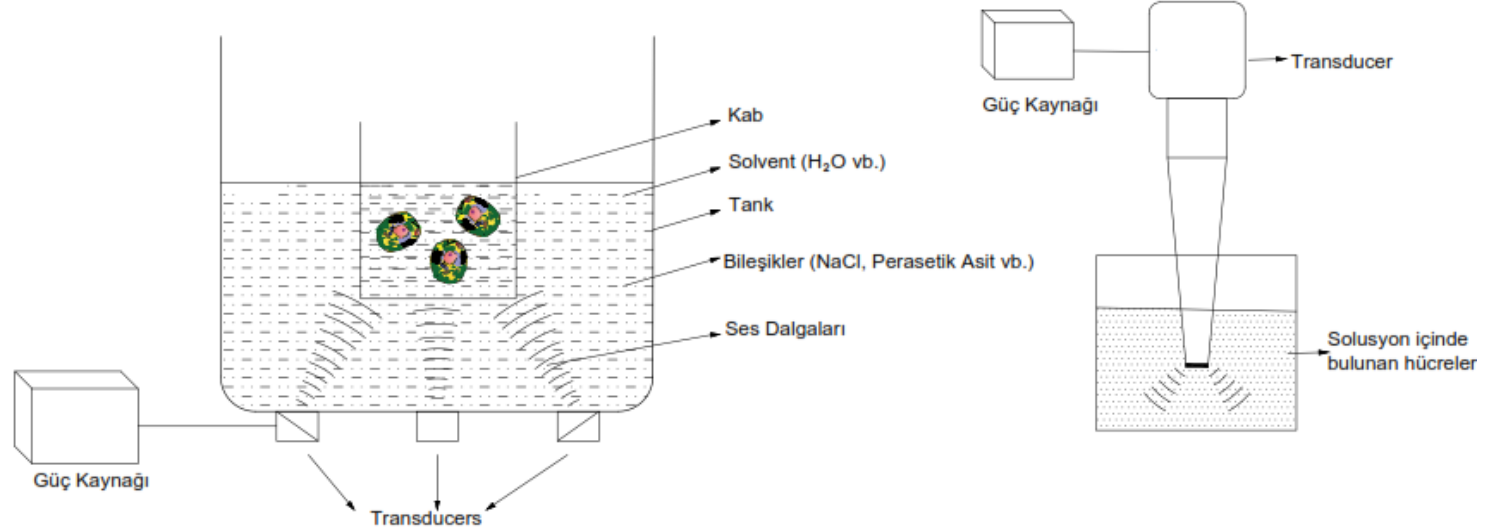

Şekil 1. a) Ultrasonik ses dalgasının bir kap içinde bulunan hücre solusyonuna uygulanış yöntemi, b) Ses dalgasının sonikatör kullanarak uygulanması (Sao Jose ve ark., 2014' den değiştirlerek hazırlanmıştır)

Figure 1. a) Application of ultrasound on cell suspension in a cap, b) Application of soundwave via sonicator (modified from the work of Sao Jose et al., 2014)

Ses dalgasının kullanım alanları ve organizmaların gösterdiği tepkiler:

Ultrases dalgası gıda endüstrisinde gittikçe önem kazanan bir teknolojidir. Son yıllarda temiz teknolojiler (emerging technologies) olarak gündeme gelen yüksek basınç, elektrik akımı ile elektrolize edilmiş su, ışıma, ozon ve ultrases tatbiki gibi yöntemler gıda endüstrisinde ve tarımsal faaliyet alanlarında en çok kullanılan yöntemler olmuştur (Fava ve ark., 2011). Sarvaiya ve Kothari (2015) duyulabilen ses dalgasının (38-689 Hz) müzik olarak prokaryotik ve eukaryotik organizmalara uygulandığında büyüme, metabolizma ve antibiyotik hassasiyetini arttırdığını ve mikroorganizmaların antibiyotiğe maruz bırakıldıklarında müzik altında daha az gelişim gösterdiğini belirlemişlerdir.
Ultrasonik teknoloji, dental ve medikal aletlerin dezenfeksiyonunda ve mikrobiyal etmenlerin inaktivasyonunda kullanıldığı gibi beton yapıların içinde oluşan yarık, hata ve noksanlık gibi kusurları anlamak ve hatta hayvanlar ile iletişim sağlamak (köpek ıslığı) gibi birçok alanda geniş kullanım alanına sahiptir. Ultrases dalgaları ile ilgili çalışmaların başlangıcı 20. yüzyıl başlarına giderken, çalışmaların dikkat çeken bölümü 2000 yılından sonra başlamıştır (Mason, 2003). Doğada, yarasa ve yunus balıkları gibi canlılar düşük yoğunluklu ultrases sinyalleri göndererek avlarının yerlerini belirlerlerken, balinalar gibi bazı deniz canlılarının ise yüksek yoğunluklu ultrases sinyalleri göndererek avlarını sersemlettikleri bilinmektedir. Yine, denizaltıların çıkardıkları sesler ile balıkların ölmesi bu alandaki çalışmaların başlaması için 
önemli bir etken olmuştur (Earnshaw ve ark., 1995).

Ticari olarak ultrases dalgası uygulamaları mikrobiyal bulaşmayı önleme, yiyeceklerin dayanıkııı̆ının arttırılması ve atık suların arıtılması gibi çeşitli alanlarda kullanım alanı bulmuştur (Quan, 2011). Yüksek frekans dalgaları ile atık suların muamelesi (sonoxide) bakteriler ve alglerin kontrolünde önemli başarılar sağlamıştır. Çünkü ses dalgası mikrobiyal suspansiyon içinde uzun mesafeleri hızlı katettiğinden (2000-3000 $\mathrm{m} \mathrm{s}^{-1}$ ) (Anonymous, 2016a) sIVI içindeki hücrelerden hızlı tepki alıp organizma üzerinde strese neden olmaktadırlar (Şekil 2a ve b).
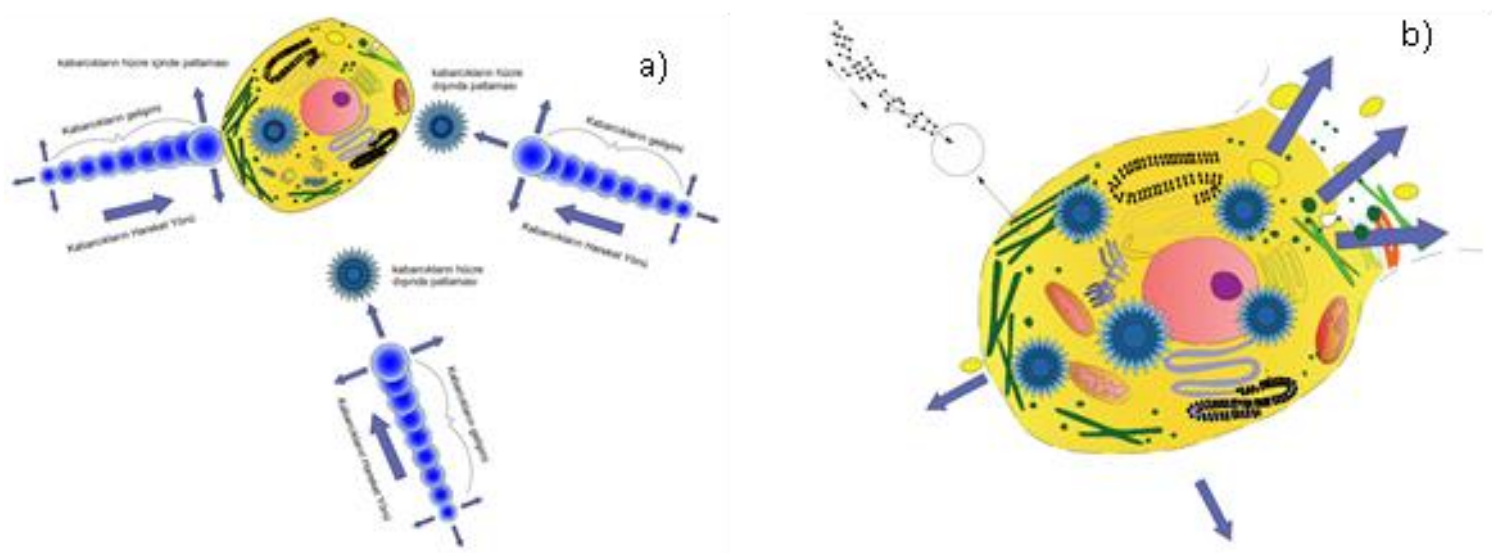

Şekil 2. a) Ses dalgasının hücre duvarına etkisi, b) ses dalgasının hücre içinde fonsiyon bozulmasına ve metabolit kaybına etkileri

Figure 2. a) Effect of soundwave on cell wall, b) effect of soundvawe on the loss of cell metabolite and disfunctioning of cell metabolism

Ses dalgası ile yapılan çalışmaların bazıları aşığıdaki başlıklar altında incelenmiştir.

\section{Ürünün raf ömrüne etkileri:}

Meyve ve sebze gibi gıda maddelerinin üzerinden mikroorganizmaların arındırıması edilmesi son yıllarda gelişen hayat standartları ile birlikte tüketicilerin önemli talepleri arasında yer almıştır. Mikroorganizmaların inaktivasyonu için ısıl işlemler (pasterizasyon ve yüksek sıcaklık) gibi klasik metotlar kullanıldığından, bu işlemler sonucu istenmeyen tat ve besin kaybı oluşmakta, dolayısı ile tüketiciler uzun raf ömrü ile birlikte kalite ve kantite kaybının en az olmasını talep etmektedirler. Ancak, bu parametreleri en iyi muhafaza edecek teknolojilerin çevreye duyarlı ve güvenilir olmasının gerektiği bilinmelidir. Ultrases dalgasının sebze ve meyvelerde uygulanması son zamanlarda ortaya çıkan en etkili bitki koruma stratejileri arasına girmiştir (Sao Jose ve Vanetti, 2012; Alexandre ve ark., 2013). Ultrases dalgası non-termal teknoloji olup ürünün raf ömrünü uzatan, besin, tat ve görsel özelliklerini bozmadan dayanıklılık sağlayan bir teknolojidir. Özellikle, ısıya hassas ürünlerin muhafazasında çok faydalı bir tekniktir (Wang ve ark., 2011; Bhat ve ark., 2011). Bu teknik, emniyet, sağlık ve çevre dostu oluşu yönünden büyük avantaj sahibidir (Kentish ve Ashokkumar, 2011). Örneğin, Cao ve ark. (2010) farklı frekanslarda ultrases dalgasını (0-, 25-, 28-, 40- ve $59 \mathrm{kHz}$ ) çilekler üzerinde denemişler (10 dakika, $20^{\circ} \mathrm{C}$ ) ve $5{ }^{\circ} \mathrm{C}$ de 8 gün süre ile depolamışlardır, $40 \mathrm{kHz}$ ultrases dalgası, meyve sertliğini muhazfaza ederken, titre 
edilebilen asit, toplam çözünen madde miktarı ve vitamin $C$ içeriklerinde herhangi bir kayba neden olmadığı gibi meyve üzerinde bulunan mikroorganizma sayısını da azaltmıştır. Daha düşük düzeydeki ultrases dalgasının $(25-28 \mathrm{kHz})$ meyve çürümesi ve kalite üzerinde herhangi bir etkisinin olmadığı da rapor edilmiştir. Yine, Aday ve ark. (2013) 30 veya $60 \mathrm{~W}$ gücünde bir ultrases dalgasının 5 veya 10 dakikalık bir uygulama ile depolanmış çilek meyvelelerinde raf ömrünü uzattığını, meyvelerin toplam çözünen madde içeriği, renk ve şeker içeriklerinde artış sağladığını belirlemişlerdir.

Bugüne kadar yapılan çalışmaların bazıları Çizelge 1'de özetlenmiştir. Çalışmalardan da görüleceği üzere, yayınların büyük çoğunluğu fiziksel temizleme üzerine yoğunlaşmıştır.

Çizelge 1. Ses dalgaları ile yapılan bazı çalışmalar.

Table 1. Some studies with sound waves.

\begin{tabular}{|c|c|c|c|c|}
\hline Ürün & Ses dalgaları & Uygulama & $\begin{array}{l}\text { Mikrobiyal } \\
\text { azalım, } \\
\left(\text { Log } c f u ~ g^{-1}\right)\end{array}$ & Referans \\
\hline Çilek & $40 \mathrm{kHz}, 20^{\circ} \mathrm{C}, 10$ dak. & US* & 0.6 & Cao ve ark. (2010) \\
\hline Marul & $40 \mathrm{kHz}, 20^{\circ} \mathrm{C}, 10$ dak. & $\mathrm{US}+50 \mathrm{mg} \mathrm{l}^{-1} \mathrm{NaOCl}$ & 1.2 & $\begin{array}{l}\text { Seymour ve ark. } \\
(2002)\end{array}$ \\
\hline Marul & $\begin{array}{l}40 \mathrm{kHz}, 30 \mathrm{~W} \mathrm{I}^{-1}, 10 \\
\text { dak. }\end{array}$ & $\begin{array}{l}\text { US }+\% 2(\mathrm{v} / \mathrm{v})^{\prime} \quad \text { lik } \\
\text { Laktik, sitrik and malik } \\
\text { asit }\end{array}$ & 2.7 & $\begin{array}{l}\text { Sagong ve ark. } \\
\text { (2011) }\end{array}$ \\
\hline Marul & $\begin{array}{l}20 \mathrm{kHz}, 280 \mathrm{~W} \mathrm{I}^{-1}, 53 \\
\text { dak. }\end{array}$ & US & 4.4 & $\begin{array}{l}\text { Elizaquivel ve ark. } \\
\text { (2012) }\end{array}$ \\
\hline Ispanak & $\begin{array}{l}21.2 \mathrm{kHz}, 200 \mathrm{~W} \mathrm{I}^{-1}, 2 \\
\text { dak. }\end{array}$ & $\begin{array}{l}\text { US + Salisilik asit (0.05 } \\
\left.\mathrm{mmol} \mathrm{I}^{-1}\right)\end{array}$ & - & Yang ve ark. (2011) \\
\hline $\begin{array}{l}\text { Cherry } \\
\text { domates }\end{array}$ & $40 \mathrm{kHz}, 24^{\circ} \mathrm{C}, 10$ dak. & $\begin{array}{l}\text { US + Perasetik asit (40 } \\
\left.\mathrm{mg}^{-1}\right)\end{array}$ & 4 & $\begin{array}{l}\text { Sao Jose ve Vanetti } \\
(2012)\end{array}$ \\
\hline Elma & 170 kHz, 10 dak. & $\mathrm{US}+\mathrm{ClO}_{2}\left(20 \mathrm{mg} \mathrm{l}^{-1}\right)$ & 4 & $\begin{array}{l}\text { Huang ve ark. } \\
(2006)\end{array}$ \\
\hline Japon Eriği & $40 \mathrm{kHz}, 20^{\circ} \mathrm{C}, 10$ dak. & $\mathrm{US}+\mathrm{ClO}_{2}\left(20 \mathrm{mg} \mathrm{l}^{-1}\right)$ & 3.0 & Chen ve Zhu (2011) \\
\hline $\begin{array}{l}\text { Brokkoli } \\
\text { tohumları }\end{array}$ & $40 \mathrm{kHz}, 23^{\circ} \mathrm{C}, 30$ dak. & US & 1.04 & Kim ve ark. (2006) \\
\hline Çin lahanası & $40 \mathrm{kHz}, 23^{\circ} \mathrm{C}, 3$ dak. & US + elektrolize su & 2.6 & $\begin{array}{l}\text { Forghani ve Oh } \\
\text { (2013) }\end{array}$ \\
\hline $\begin{array}{l}\text { Susam } \\
\text { yaprağı }\end{array}$ & $40 \mathrm{kHz}, 23^{\circ} \mathrm{C}, 3$ dak. & US + elektrolize su & 2.33 & $\begin{array}{l}\text { Forghani ve Oh } \\
(2013)\end{array}$ \\
\hline $\begin{array}{l}\text { Kırmızı } \\
\text { biber }\end{array}$ & $35 \mathrm{kHz}, 15^{\circ} \mathrm{C}$. & US & 1.98 & $\begin{array}{l}\text { Alexandre ve ark. } \\
\text { (2013) }\end{array}$ \\
\hline Yer mantarı & $35 \mathrm{kHz}, 10^{\circ} \mathrm{C}, 4$ dak. & $\begin{array}{l}\text { US + Ethanol (\%70, } \\
\mathrm{v} / \mathrm{v})\end{array}$ & 3.5 & $\begin{array}{l}\text { Rivera ve ark. } \\
(2011)\end{array}$ \\
\hline
\end{tabular}

Genellikle, marul, Ispanak, soyulmuş ve dilimlenmiş havuç, domates (özellikle cherry tipinde olanlar), çilek ve üzüm gibi yaş sebze ve meyveler, çoğunlukla bu yolla muamele edilen ürünlerdir. Ancak araştırıcılar, son yıllarda ultrases dalgasının etkinliğini optimize etmek için çeşitli alternatifler de önermişlerdir. Ultrases dalgasının frekansı, dalga genişliği, ortamda bulunan sıvının akışkanlığı ve sıcaklığı kavitasyon derecesini etkileyen önemli faktörler olduğundan (Piyasena ve ark., 2003), uygulamalarda 
genellikle, $20-45 \mathrm{kHz}$ arası frekanslar ve 1 ila 10 dakikalık süreler test edilmiştir. Ultrases dalgaları ile yapılan çalışmalara yukarıda bahsedilen kriterlerin yanında mikroorganizma yoğunluğunun da etkili olduğu bilinmektedir (Huang ve ark., 2006; Sagong ve ark., 2011; Sao Jose ve Vanetti, 2012; Alexandre ve ark., 2013). Örneğin, Seymour ve ark. (2002) musluk suyu, klorlanmış su (25 ppm) ve ultrases dalgasına maruz bırakılmıs $\left(10 \mathrm{~W} \mathrm{I}^{-1}, 32-40 \mathrm{kHz}, 10\right.$ dakika) su olmak üzere 3 farklı suyu marul, salatalık, havuç, biber, soğan, maydanoz, çilek, nane gibi bitkilerde bulaşık olarak bulunan Salmonella typhimurium, Escherichia coli ve Listeria monocytogenes'e karşı denemişlerdir. Basit yıkama, mikrobiyal kontaminasyonu biberlerde $1.43 \log _{10} \mathrm{cfu}^{-1}$ azaltırken, ultrases dalgasına maruz kalmış su ile birlikte yıkama $1.98 \quad \log _{10} \quad \mathrm{cfu} \quad \mathrm{g}^{-1}$ azaltmıştır. $\mathrm{Bu}$ mikroorganizmaların ampicillin adlı antibiyotiğe dayanıklı olduğu göz önüne alındığında elde edilen sonuçların çok etkileyici olduğu görülmüştür. Lopez ve ark. (1994) $20 \mathrm{kHz}$ frekansında bir ultrases dalgasının soya fasülyesinde lipoxygenase (LOX, olgunlaşmayı sağlayan enzim) aktvitesi üzerine etkinliğini test etmişler, meyve ve sebzelerin raf ömrünü bahsi geçen enzimi inaktif hale getirerek uzatmışlardır. Benzer rapor, Lopez ve Burgos (1995) tarafından da yapılmıştır. Bulgular, kısa ömürlü $\mathrm{OH}^{-}$ radikallerinin uzun ömürlü $\mathrm{H}_{2} \mathrm{O}_{2}$ ya dönmesi ile LOX inaktivasyonunun gerçekleştiğini göstermiştir. Meyve enzimleri genellikle meyvenin kahverengileşmesine ve vitamin $C$ kaybına neden olur. Örneğin, peroxidase (POD) enziminin varlığı ham meyve ve sebzelerde veya iyi dondurulmamış meyve ve sebzelerde tat ve renk kaybı ile yakından ilgilidir, dolayısı ile soğuk koşullar, POD enziminin inaktivasyonuna katkıda bulunduğundan, sebze ve meyveler bu koşullarda daha uzun ömürlü olurlar (Ercan ve Soysal, 2011). Isıl koşullar da bu enzimi inaktif hale getirecek potansiyele sahip olmasına rağmen, bu enzimin hem ısıya karşı dayanıklılık göstermesi hem de ısıl işlem sırasında meyve ve sebzelerde renk, tat ve koku kaybı, bu işlemin en önemli dezavantajıdır (Cruz ve ark., 2006). Örneğin, Bacillus ve Clostridium türleri zıt koşullara oldukça dayanıklı bakterilerdir. Bacillus thermophiles sporları $100{ }^{\circ} \mathrm{C}^{\prime}$ de 4 saat muamele olduktan sonra ancak imha edilmişlerdir. Yine, Bacillus subtilis sporların denature olması oldukça zordur (Ladeira ve ark., 2015). Birçok geliştirilen yeni tekniğin başarısı bu sporların etkisiz hale getirilmesindeki başarıya bağlıdır. Polyphenol oksidaz (PPO) enzimi de meyve ve sebzelerde kahverengileşme ile ilgili bir diğer enzimdir. Meyvelerde sertlik kaybı genellikle enzimatik reaksiyonlar sonucu hücre duvarı ve orta lamel tabakasının parçalanması ile başlar. Birçok enzim (phenylmethyl esterase, polygalacturonase, beta galactosidase ve cellulase) pektin tabakasının parçalanmasında etkin rol oynar. Örneğin, pectinmethylesterase enzimi ve polygalacturonase enzimleri hücre duvarlarında bulunan pektin yapısını parçalayarak dokunun geçirgenliğini arttırır (Raviyan ve ark., 2005). Dolayısı ile bu enzimlerin inaktivasyonu meyvelerin yumuşamasının önüne geçerek raf ömrünü uzatacaktır. Raviyan ve ark. (2005) ultrases dalgasını domateste kullanarak bu enzimlerin inaktivasyonunun ortamda $\mathrm{H}_{2} \mathrm{O}_{2}$ üretimi ile ilişkili olduğunu ortaya koymuştur. $\mathrm{Bu}$ durum, Mawson ve ark. (2011) ile de uyumlu bulunmuştur. Ancak dokuda $\mathrm{H}_{2} \mathrm{O}_{2}$ ve diğer oksidant moleküllerin birikimi ile hem dokunun antioksidant seviyesinin azalacağı hem de bu stres metabolitlerine tolerant fungus ırklarının ortaya çıkacağı göz ardı 
edilmemelidir. Özellikle, meyve ve sebzelerin dilimlenerek depolanması aşamasında olgunlaşmayı sağlayan ve kahverengileşmeye neden olan enzimlerin hızlı inaktive edilmesi ve stres metabolitleri oluşmadan depolama sürecinin başarılı geçmesi insan ve çevre sağlığı açısından oldukça önemlidir. Örneğin, Alexandre ve ark. (2012) ultrases dalgası (35 $\mathrm{kHz}$ ) ile muamele edilen çilek meyvelerinin antosiyanin seviyesinin kimyasal çözelti ile yıkanan meyvelerden daha yüksek olduğunu 6 günlük oda sıcaklığında depolama sonucu rapor etmişlerdir. Tiwari ve ark. (2009) benzer bir çalışmada, $20 \mathrm{kHz}$ lik bir ultrases dalgasının çilek suyunun mevcut antosiyanin seviyesini koruduğunu belirlemişlerdir. Tiwari ve ark. (2010) benzer sonuçları, üzüm suyu ile yapılan çalışmada da elde etmişlerdir. Muhafaza sırasında en çabuk bozulma ve kaybolma özelliği gösteren vitamin $C$ seviyesi bu sayede korunmuştur. Yine, Ercan ve Soysal (2011) 23 kHz'de 75\% güçte 90 saniye süre ile uygulanan ultrases dalgasının domates suyunun vitamin $\mathrm{C}$ içeriğini koruduğunu göstermişlerdir. Vitamin $C$ içeriği meyve rengi konsantrasyonu ile doğru orantılı olduğundan meyvelerin renk durumu, kalitesi hakkında bilgi vermektedir (Tiwari ve ark., 2009). Özellikle, klorofil, karotenoid ve antosiyanin önemli pigmentlerdir. Hasat sonrası bu pigmentler parçalanarak renk kademeli olarak açılmaya başlar, bu durum meyve ve sebzelerin kabul edilebilirlik oranı ile vitamin ve antioksidant değerlerini de düşürür. Ultrases dalgası ile meyve ve sebzelerde pigment parçalanmasının önüne geçilmesi mümkün iken burada dikkat edilmesi gereken husus yüksek performansta uzun süre kullanılan ultrases dalgasının olumsuz etki yapacağının bilinmesidir. Örneğin, Chen ve ark. (2012) Guiwei bitkisini ultrases ile 120 W'da 10 dakika muamele ederek oda sıcaklığında muhafaza etmişler, antosiyanin, PPO ve POD enzim aktivitesini erken safhada engellemeyi başararak meyvelerin raf ömrünü uzatmışlardır. Yine, Yang ve ark. (2003) ultrases ile askorbik asidin birlikte engelleyici etkisinin enzimler üzerinde olumsuz etkisini göstermişlerdir. Meyve ve sebzelerin kalitesi zengin vitamin kaynağına, fenolik bileşiklerine, organik asit, flavonoid, şeker ve lif içeriğine bağlıdır. Bu özellikler meyveyi paraziter ve abioyotik stres faktörlerinden korumada önemli rol oynarken insan sağlığı açısından da değerli metabolitleri ve aromayı içerirler. Hasat sonrası meyve ve sebzelerde solunum ön plana çıktığı için ultrases dalgası uygulaması ile solunum kesintiye uğratılıp yavaşlatıldığından metabolit ve aroma kaybı da engellenmiş olup yaşlanma hızı da yavaşlatılmaktadır. Son çalışmalar, yaşlılık sürecininin ve hızının serbest oksijen radikallerinin konsantrasyonuna bağlı olduğunu ve bunun mitokondrial proteinlere zarar verdiğini ortaya koymuştur ( $\mathrm{Dr}$ Karel Angelis ile kişisel görüşme, 2015, Belçika). Buna karşılık bitkiler, superoxide dismutase (SOD), catalase (CAT) ve peroxidase (POD) gibi enzimler ile serbest radikalleri parçalayarak azaltma potansiyeline sahiptirler. Burada dikkat edilmesi gereken husus ultrases dalgasının mikroorganizmalar üzerinde serbest radikal oluşumunu sağlarken sebze ve meyvelerin kalitesi üzerinde olumsuz etki yapmayacak düzeyde tutulmasıdır. Li ve ark. (2007) hasat sonrası şeftalilerin ultrases $(50 \mathrm{kHz}, 200 \mathrm{~W})$ ve $\mathrm{CaCl}_{2}$ $(3 \%, \mathrm{w} / \mathrm{v})$ ile 3 dakika muamele edilmesinin meyvelerde SOD ve CAT aktivitesini arttırırken POD aktivitesi, $\mathrm{O}_{2}^{-}$ve $\mathrm{H}_{2} \mathrm{O}_{2}$ içeriğinin azalmasına neden olduğunu belirlemişlerdir. Bu alanda iyi ve güvenilir sonuçlar elde edilmesine rağmen ultrases metodu hakkında hala tam olarak kabul 
edilmiş bir protokol yoktur. Çünkü metodun süresi, frekansı ve gücü yanında uygulama sıcaklığı, ve her meyve ve sebze için optimizasyonu gereklidir (Ashokkumar ve ark., 2008). Örneğin, 47 kHz frekansta bir ultrases dalgasının biberlerde hücre duvarını parçladığı belirlenmiştir (Gabldon-Levya ve ark., 2007). Ayrıca, enerji harcamasının büyük boyutta oluşu bu teknolojinin geniş alanlara uygulanmasında en önemli engeldir.

\section{Gıdaların muhafazasına etkileri:}

Özellikle son yıllarda hazır gıda maddelerinin tüketimi hızla arttığından, bu alanda faaliyet gösteren gıda sektörü de önemli gelişmeler kaydetmiştir. Örneğin, $E$. coli bakterisi, elma sularında $5 \log _{10} \mathrm{cfu} \mathrm{ml}^{-1}$ azaltılmış yani $10^{5} \mathrm{kez}$ bakteri populasyonu düşürülmüştür (D'Amico ve ark., 2006). Yine aynı şeklide, sütlerde Listeria monocytogenes $5 \log _{10} \mathrm{cfu} \mathrm{ml^{-1 }}$ azaltılmıştır (D'Amico ve ark. 2006). Son yıllarda tüketiciler genellikle buzdolabında muhafaza edilmiş ancak tüketim anında "taze-gibi" olan ürünleri tüketme gayreti içinde olduklarından, yani derin dondurucuda bekletilen gida maddelerinden gerek lezzet gerekse "defrost" yani buzdan çözünme işlemi sırasında kullanılan mikrodalga gibi teknolojilerden uzak durma yolunu tercih ettiklerinden, ürünlerin depolama aşamasında daha az besin değeri kaybına yol açan, fiziksel ve kimyasal yapıyı değiştirmeyen alternatif teknolojleri tercih etmektedirler. Mikroorganizmalar, yiyeceklerin bozulması aşamasında sadece ürettikleri enzimler ile fiziksel ve kimyasal yapıyı bozmakla kalmayıp, çıkardıkları toksinler ile insan sağı̆̆ı̆na da zararlı olmaktadırlar. Termal yöntemler ile dezenfeksiyon işlemi sırasında yiyeceklerin kalitesi etkilendiğinden daha güvenli metotların kullanılması teknolojik gelişmelere paralel olarak benimsenir olmuştur.

Ultrases dalgası tek başına kullanılacaksa sürenin ya da gücün yükseltilmesi gündeme gelebilir, fakat bu durum hedef olmayan organizmalar için zararlı olabilir. Bu tekniğin, $\mathrm{pH}, \mathbf{I S I}$, basınç veya diğer kimyasallar ile kullanımı daha etkili bir yöntem olarak görülmektedir. Buna göre, termosonikasyon (Isı+sonikasyon),

manosonic (basınç+sonikasyon), manotermosonic (ısı+basınç+sonikasyon) en etkili metotlar olarak değerlendirilmiştir. Çünkü, geleneksel olarak, gıdaların muhafazası sırasında termal pasterizasyon işlemi uygulanırken ortam asidik bir yapıya dönüşmekte bu da $E$. coli, Salmonella gibi mikrobial patojenlerin adaptasyon ve virulenslik kabiliyetlerinin artmasına yol açmaktadır (Hammack ve ark., 2001). Çünkü, uzun süre düşük $\mathrm{pH}$ stresine maruz kalan bakteriler ortama adapte olduktan sonra tekrar çoğalma eğilimine girerler. Örneğin, Oyarzabal ve ark. (2003) E. coli 0157:H7 ırkının elma, portakal, ananas ve üzüm suyunda 12 hafta boyunca asidik koşullarda canlıı̆ıını koruduğunu tespit etmişlerdir. Mikroorganizmalar, sadece farklı pH koşullarına adapte olmakla kalmayıp sıcaklık, kuraklık ve tuzluluk gibi abiyotik stres faktörlerine karşı da hem tolerans göstermekte hem de uzun vadede bu streslere adapte olabilmektedirler (Dikilitas ve Karakas, 2014). Örneğin, Ölü denizden izole edilen Gymnascella marismortui, Ulocladium chlamydosporum and Penicillium westlingii adlı fungal etmenler yüksek tuz konsantrasyonunu çok rahat şekilde tolere etmişlerdir (340 $\mathrm{g} \mathrm{l}^{-1}$ tuz) (Buchalo ve ark., 1998).

\section{Tohum çimlenmesi üzerine etkileri:}

Ses dalgaları çimlenmekte olan tohumlara ya da çimlenme kabiliyeti düşük tohumlara 
uygulandığında olumlu etkisi görülmüş, tohumlardaki metabolik faaliyetlerin arttığı belirlenmiştir. Örneğin, bamya ve kabak tohumlarına kuş sesi ya da yankı olarak gelen ses dalgaları tohumların çimlenme yüzdesini arttırmıştır (Creath ve Schwartz, 2004). Buğday tohum ve fidelerine $5 \mathrm{kHz}$ frekansında $92 \mathrm{~dB}$ gücünde uygulandığında kök gelişiminin hızlandığı ve bitki organik ağırlığının arttığı ifade edilmiştir (Weinberger ve Measures, 1979). Cai ve ark. (2014) $2 \mathrm{kHz}$ ve $90 \mathrm{~dB}$ gücünde bir ses dalgasının Vigna radiate bitkilerinde çimlenme süresini kısaltarak gelişimi hızlandırdığını belirlemişlerdir. Wang ve ark. (2003) ise çeltik tohumlarında çimlenme indeksi, gövde uzunluğu ve yaş ağırlık artışının $0.4 \mathrm{kHz}$ frekans ve $106 \mathrm{~dB}$ ile başarılabildiğini, ancak ses dalgasının, $4 \mathrm{kHz}$ ve $111 \mathrm{~dB}$ lik bir gücü aştığında çeltik tohumlarına inhibe edici özellikte olduğunu belirlemişlerdir. Ses dalgalarının organizma üzerinde gözle görülebilir bir etkisinin olduğu Gagliano ve ark. (2012) tarafından mısır tohumları üzerinde de gösterilmiştir. Çimlenen mısır tohumlarına sürekli olarak $0.3 \mathrm{kHz}$ frekansta uygulanan ses dalgasının mısır köklerinin, ses kaynağına doğru yönelmesine yol açtığını bildirmişlerdir. Uchida ve Yamamoto (2002) ise $40-120 \mathrm{~Hz}$ frekanslık bir ses dalgasının Arabidopsis thaliana tohumlarına uygulandığında $70 \mathrm{~Hz}$ lik bir frekansın çimlenme oranı ve hızını arttırdığını, çimlenme hızındaki artış ile birlikte etilen hormon aktivitesinin de arttığını rapor etmişlerdir. Yi ve ark. (2003) ses dalgasının (1 $\mathrm{kHz}, 100 \mathrm{~dB}$ ) krizantem bitkilerinin köklerini uyararak gelişimini hızlandırdığını, çözünebilen şeker, protein ve amilaz aktivitesini arttırdığını belirlemişlerdir.
Doku gelişimine etkileri:

$\begin{array}{ccc}\text { Ses dalgaları çeşitli } & \text { bitkilere } \\ \text { uygulandığında onların } & \text { aromatik }\end{array}$
bileşenlerinin artışına da katkıda bulunmuştur. Actinidia chinensis (Yang ve ark., 2004), krizantem (Shao ve ark., 2008) ve Dendrobium candidum (Li ve ark., 2008) üzerinde uygulanan ses dalgası ile hormon ve enzim seviyeleri arttırılmıştır. Örneğin, $A$. chinensis bitkisinde $1 \mathrm{kHz}$ frekansında $100 \mathrm{~dB}$ şiddetinde uygulanan ses dalgası ile ATP sentezinde artış başarılmış ve hücre dayanklılığı sağlanmıştır. Benzer durum SOD, CAT ve POD için de geçerlidir. Yaprak, kök ve gövdede artış gösteren enzim seviyesi malondialdehyde seviyesinde azalma ile korelasyon göstermiştir. Ancak, ses dalgası 1 $\mathrm{kHz}$ ve $100 \mathrm{~dB}$ seviyesini geçtiğinde yukarıda bahsedilen değerlerde düşüş yaşanmıştır (Yang ve ark., 2003). SOD ve CAT enzimleri $\mathrm{O}_{2}^{-}$radikal iyonlarının $\mathrm{O}_{2}$ ve $\mathrm{H}_{2} \mathrm{O}_{2}$ moleküllerine ayrılmasında önemli rol üstlenmektedir. Dolayısı ile bu enzimin seviyesinde görülen artış, stres metabolitlerinin azaltılması için önemli bir kaynaktır. Takahashi ve ark. (1991) çimlenen çeltik ve hıyar tohumlarına 2 saat süre ile uygulanan $50 \mathrm{~Hz}$ lik bir titreşimin hipokotil uzunluğuna olumlu katkıda bulunduğunu bildirmişlerdir. Benzer sonuçlar Arabidopsis bitkisi için de yapılmıştır (Johnson ve ark., 1998). Ses dalgaları, dokularda hormon seviyelerinin değişimine de katkıda bulunmaktadır. Örneğin, Bochu ve ark. (2001) 1.4 kHz frekasında $95 \mathrm{~dB}$ gücündeki bir ses dalgasının 10 gün süre ile krizantem bitkilerine uygulandığında, indol asetik asit (IAA) seviyesinde artışa, absisik asit (ABA) seviyesinde ise azalmaya neden olduğunu saptamışlardır. Bu oransal durum, doku oluşumunu hızlandırdığı gibi farklı doku oluşumuna da yol açmıştır. 
Yine, Yiyao ve ark. (2002) belirli ses dalgalarının krizantem bitkisinin gelişimine katkıda bulunduğunu, fakat ses dalgasının enerji seviyesi yükseldiğinde ise tam tersi bir durum oluştuğunu belirlemişlerdir. Örneğin, düşük frekansdaki ses dalgasının meydana getirdiği titreşimlerin bitki veya tohumlar üzerinde olumlu katkı yaptığı bilindiği gibi yüksek frekanslı ses dalgalarının da olumsuz etkisi söz konusudur (Chivukula ve Ramaswamy, 2014). Hatta yüksek titreşimli ses dalgaları düşük ses ayarında bile hassas bitkilere ölümcül etki yapabilmektedir (Chivukula ve Ramaswamy, 2014). Burada, sesin şiddeti yanında frekansı ve bitkinin hassasiyeti göz önüne alınmalıdır.

Hücre genetiği ve metabolizma üzerine etkileri:

Son yıllarda ses dalgasının bitki dayanıklııı̆ını arttırdığı ve kimyasal gübre ve pestisit kullanımını azalttığı yönünde kanıtlar da mevcuttur (Zhang, 2012). Ses dalgalarının bitki yapraklarını titreterek stomaların açıımasını uyardığı ve bitkinin daha fazla nem ve besin içeriğini absorbe ederek hücre içindeki protoplazmik hareketleri arttırdığı, dolayısı ile bitkilerde metabolit sentezinin hızlandığı tespit edilmiştir (Anonymous, 2016b). Ses dalgasının bu özelliği, herbisit çalışmalarında da kullanılmıştır. Böylece olgunlaşmış yabancı otlar \% 50 daha az total herbisit veya selektif herbisit ile kontrol edilmiştir (Carlson, 2013). Ses ve ışık enerjisi yaprak üzerinde birlikte kullanıldığında her iki enerji toplamının kimyasal enerji olarak depo edildiği ve fotosentez oranında artış kaydedildiği belirlenmiştir (Meng ve ark., 2012).

Ses dalgası bitkilerde hücre döngüsünü etkileyecek potansiyele de sahiptir. Hücre büyümesi; hücre çoğalması ve başkalaşması olarak kabul edildiğinden, hücre büyümesini hücre döngüsü olarak görmek de mümkündür. Normal hücrelerde, hücre bölünmesi 4 aşamadan oluşur. Bunlar;

$\mathrm{G}_{1}$ safhası (DNA çoğalması için hazırlık safhası)

$S$ safhası (DNA çoğalması)

$G_{2}$ safhası (mitoz bölünme için hazırlık safhası)

M safhası (mitoz bölünme safhası)

$S$ safhası (sentez safhası) hücre döngüsünde DNA nın çoğaltıldığı $G_{1}$ ve $G_{2}$ safhaları arasında kalan safhadır. Tam ve doğru DNA replikasyonu, hücre ölümü ve hastalığa yol açan genetik anormalliklerin önlenmesi için gerekli bir safhadır (Depamphilis, 2003). Ses dalgasının Ssafhasını kısaltması üzerine katkı yaptığına dair çeşitli çalışmalar mevcuttur. Örneğin, Ekici ve ark. (2007) farklı tonlardaki klasik müziğin soğan kök hücrelerinde mitotik bölünmeyi hızlandırarak kök gelişimini teşvik ettiğini rapor etmişlerdir. Vanol ve Vaidya (2014) bitkilerin klasik müzik, rock müzik ve trafik gürültüsünü hissedibilecek bir mekanizmaya sahip olduklarını öne sürmüşlerdir. Yapılan çalışmalar sonucunda yaygın kanaat sesin türünden ziyade ses dalgasının frekans ve şiddetinin organizmalar üzerinde etki yaptığı şeklinde oluşmuştur. Çünkü, yukarıdaki çalışmayı destekleyecek daha fazla veri, bitki ve müzik türüne ihtiyaç olup aynı mekanizmanın diğer bitki ve canlılar için geçerli olup olmadığının belirlenmesi gerekmektedir.

Ses dalgalarının frekans, $d B$, süre yanında organizmaya olan uzaklığı bitkiler üzerinde denenmiş, $1 \mathrm{kHz}$ frekansında $100 \mathrm{~dB}$ lik bir güç 1 saat süre ile bitkilerden $0.20 \mathrm{~m}$ uzaklıkta tutulduğunda hücre bölünmesi, enzim ve hormon seviyesinde artışa neden olmuştur. Ses dalgaları plasma $\mathrm{H}^{+}$-ATPase 
aktivitesinde artışa neden olduğu gibi RNA miktarı ve genetik kopyalama fonksiyonlarında da pozitif katkı yapmıştır (Chowdhury ve ark., 2014).

Ses dalgalarının katkısı sadece biyokimyasal seviyede ölçülmemiş aynı zamanda verime katkısı da ele alınmıştır. Örneğin, 0.1-1 kHz arasında değişen ses dalgaları $70 \mathrm{~dB}$ lik bir güçte 3 saat boyunca 30-60 cm arasında her gün biber, salatalık ve domates bitkilerine uygulandığında, verimi sırası ile \% 30, 37 ve 13 oranında arttırdığı tespit edilmiştir (Hassanien ve ark., 2014). Yine, aynı şekilde, marul, ıspanak, pirinç ve buğday verimi $\% 20,11,5.7$ ve 17 olarak artmıştır. Ses dalgasının, arılar, afitler, gri çürüklük, geç yanıklık ve virus hastalıkları gibi seralarda problem olan etmenlere karşı da başarılı bir şeklide kullanılma potansiyeli mevcuttur.

Ses dalgası DNA miktarı üzerine gözle görülür bir katkı yapmasa bile, RNA sentezini ve çözünebilen protein sentezini arttırmıştır (Shao ve ark., 2008). Yine, Xiujuan ve ark. (2003) ses dalgasının ( $1 \mathrm{kHz}, 100 \mathrm{~dB})$ DNA miktarı üzerine olumlu bir katkısının olmadığını ancak RNA sentezi ve çözünebilen protein miktarı üzerinde hızlandrıcı etkisinin olduğunu ifade etmişlerdir. Benzer sonuçlar, Xiaocheng ve ark. (2003) tarafından Actinidia chinensis için rapor edilmiş ve $1 \mathrm{kHz}$ ve 100 $\mathrm{dB}$ gücünde bir ses dalgasının kallus üzerinde enerji metabolizmasını harekete geçirerek ATP sentezini arttırdığı görülmüştür.

Ses dalgası hücre membranının yapısını değiştirebilecek güce de sahiptir. Bir başka ifade ile, frekans arttığında hücre membranındaki deformasyon da artmaktadır (Bochu ve ark., 2003). Dışarıdan uygulanan mekanik uyarı sistemlerinin bitkide sinyal iletişim mekanizmalarını harekete geçirdiği bilinmesine rağmen (Johnson ve ark., 1998) müzik ya da gürültü olarak ele alınan ses dalgalarının bitkiler üzerindeki etkileri geçmiş zamanlarda tartışmalı bulunmuştur (Galston and Slayman, 1979). Günümüzde ise bu etki bilinmesine rağmen yeterli sayıda fizyolojik ve moleküler düzeyde çalışmalara henüz ulaşılamamıştır.

Ses dalgası hücrelerde $\mathrm{Ca}^{2+}$ değerleri üzerine de etkili bulunmuştur. Kontrol grubu hücrelerde $\mathrm{Ca}^{2+}$, vakuolde birikip diğer organellere daha az dağılım gösterirken, ses dalgası ile muamele edilen bitkilerde vakuol membranlarında birikme eğilimi göstermiştir, dolayısı ile daha fazla $\mathrm{Ca}^{2+}$ sitoplazma içine geçerek stres koşullarına adaptasyonda önemli katkı sağlamıştır (Hassanien ve ark., 2014).

Ses dalgaları ile yapılan çalışmalar açık alanı da içine almıştır. Örneğin, "Plant acoustic frequency technology, PAFT" adı verilen teknoloji ile açık alanda $0.06-2 \mathrm{kHz}$ frekanslarında 50-120 dB arasında değişen ses basıncı ile 50-100 $\mathrm{m}^{2}$ lik bir alanda yetiştirilen çileklerin yaprakları daha koyu, çiçeklenme ve meyveye yatkınlığı, muamele edilmeyen bitkilere göre 1 hafta erken gerçekleşmiştir. Hastalık ve zararlılara karşı dayanıkııı̆ın da arttığı rapor edilmiştir (Qi ve ark., 2010). Benzer sonuçlar, Ispanak, pamuk, çeltik gibi bitkilerle de başarılmış, ürün artışı genel olarak \% 5 olarak sağlanmıştır (Hou ve ark., 2010).

Ses dalgası mantar yetiştiriciliğinde de kullanılmıştır. Yaklaşık olarak \% 15 lik ağırlık artışı ile birlikte mantar çapında \% 50 oranında artış kaydedilmiştir (Jiang ve ark., 2012).

Ses dalgaları bitkilerde antioksidant enzim salgılanmasını arttırarak "bitki koruma stratejisi" ne dolaylı olarak katkıda bulunan çalışmalarda da kullanılmıştır.

Ses dalgaları, kimyasal kalıntı ve pestisit kalıntılarını meyve ve sebzelerin yüzeyinden uzaklaştırılmasında da kullanılmaktadır (Bilek 
ve Turantaş, 2013). Bu teknoloji henüz geleneksel teknolojilerin yerini almasa da onlara entegre olabilecek potansiyele sahiptir. Mekanizmanın aydınlatılması ve tutarsız sonuçların gözden geçirilmesi için daha fazla biyokimyasal ve moleküler biyoloji çalışmalarına ihtiyaç vardır.

Ses dalgası ile yapılan çalışmalara itirazlar da mevcuttur. Birincisi ses teknolojisi hem hayvanlar hem de insanlar için gürültü kirliliğine neden olmakta, hem sera hem de açık alanlarda sorun teşkil etmektedir. Bundan dolayı, ses dalgası uygulaması erken saatlerde sabah 5-9 arasında ve kısa süreli olmak durumunda kalmıştır.

\section{Sonuçlar}

Hasat edilmiş sebze ve meyveler çok çabuk bozulma sürecine girerler, patojenik ve saprofit mikroorganizmalar için zengin bir besin kaynağı oluştururlar. Bu mikroorganizmalar, ürünlerde kalite ve kantite kaybına yol açtığı gibi insan sağlığına da olumsuz yönde etki ederler. Uzun yıllar boyunca hasat edilmiş sebze ve meyvelerin muhafaza edilmesi sentetik kimyasallar yolu ile olmakta idi. Çevre ve insan sağlığı üzerine olan etkilerinden ve patojenlerin direnç kazanmasından dolayı bu metotların kullanımı ve uygulanması gittikçe kısıtlanmaktadır. Tüketiciler, son 20 yıldır dilimlenmiş olarak pazarlanan ve aynı zamanda çok az işlem görmüş gıdaları talep ettiklerinden hasat sonrası ürün kaybı çok daha fazla olmaktadır. Bu durum, ürün korumada daha yeni, etkili ve çevre dostu teknolojilerin geliştirilmesini zorunlu kılmıştır. Son yıllarda sıcaklık muamelesi, UVC, kızıl ötesi ve iyonize-radyasyon gibi yöntemlerle mikroorganizmaların kontrolünde başarılı sonuçlar elde edilmiştir. Ultrases teknolojisi ise bu alandaki mevcut metotlara fiziksel metod olarak ilave edilmiş yeni bir metotdur. Bu metodun bir diğer özelliği ise kimyasal metotlar ile uyum içinde kullanılacak potansiyele sahip olmasıdır. Bu tekniğin en önemli dezavantajı yüksek enerji tüketimi olup geniş alanlarda uygulanmasının şimdilik masrafıı oluşudur.

Ses dalgası teknolojisi bitki dayanıklılığını arttırdığı gibi kimyasal gübre ve ilaç kullanımını da azaltarak çevreye faydalı bir yaklaşım sergilemektedir. Sayıca çok ve geniş açılan stomalar ile herbisit etkiniliğinin artması, daha fazla gübre, nem ve oksijen absorbe edilmesi ile bitki gelişimine katkıda bulunması önemli unsurlardır. Bu özelliği ile diğer bitki geliştiricileri ile kombine edildiğinde kullanılan diğer kimyasalların etkinliği de artmaktadır. Ayrıca, ses frekansı ve basıncı iyi ayarlandığında fungal ve bakteriyel etmenlere karşı da kullanılarak bitki koruma açısından önemli bir katkı sağlamaktadır. Hasat sonrası ürünler üzerinde bulunan pestisit kalıntılarının da bu yolla uzaklaştırılması mümkündür. Diğer kimyasal yöntemlerde olduğu gibi organik ve inorganik maddelerden etkilenmezler. Kokusuz olduğu için rahatsızlık vermezler. Biyolojik yapıları parçaladıkları için diğer kimyasallar ile kullandıklarında onların etkisini arttırılar. Sistemin enerji harcamasının verimli ve etkili hale getirilmesi, açık alanlar ile sera ve in vitro koşullarda gürültü sorununun çevreye rahatsızlık vermeyecek şekilde giderilmesi bu metodun önünü açabilecek ve geniş alanlarda kullanımını yaygınlaştırabilecek unsurlardır.

\section{Kaynaklar}

Aday, M. S., Temizkan, R., Büyükcan, M. B., Caner, C., 2013. An innovative technique for extending shelf life of strawberry: ultrasound. LWT Food Science and Technology, 52 (2): 93-101. 
Alexandre, E. M. C., Brandão, T. R. S., Silva, C. L. M., 2012. Efficacy of non-thermal technologies and sanitizer solutions on microbial load reduction and quality retention of strawberries. Journal of Food Engineering, 108 (3): 417-426.

Alexandre, E.M.C., Brandao, T.R.S., Silva, C.L.M., 2013. Impact of non-thermal technologies and sanitizer solutions on microbial load reduction and quality factor retention of frozen red bell peppers. Innovative Food Science and Emerging Technologies, 17: 199-205.

Anonymous, 2016 a.

http://www.31mksa.com/pdf. Acces date: 15.10.2016.

Anonymous, $2016 \mathrm{~b}$.

www.buzzle.com/articles/does-musicaffect-plant-growth. Access date: 20.10.2016.

Ashokkumar, M., Sunartio, D., Kentish, S., Mawson, R., Simons, L., Vilkhu, K., 2008. Modification of food ingredients by ultrasound to improve functionality: a preliminary study on a model system. Innovative Food Science and Emerging Technologies, 9 (2): 155-160.

Bermúdez-Aguirre, D., Mobbs, T., BarbosaCánovas, G. V., 2011. Ultrasound applications in food processing. In H. Feng, G. V. Barbosa-Cánovas, \& J. Weiss (Eds.), Ultrasound Technologies for Food and Bioprocessing (pp. 64-105). New York: Springer.

Bhat, R., Kamaruddin, C.N.S.B., Liong, M.T., Karim, A.A., 2011. Sonication improves Kasturi lime (Citrus microcarpa) juice quality. Ultrasonics Sonochemistry 18: 1295-1300.

Bilek, S.E., Turantaş, F. 2013. Decontamination efficiency of high power ultrasound in the fruit and vegetable industry, a review. International Journal of Food Microbiology 166, 155-162.

Bochu, W., Hucheng, Z., Yiyao, L., Yi, J., Sakanishi, A., 2001. The effects of alternative stress on the cell membrane deformability of chrysanthemum callus cells. Colloids and surfaces B: Biointerfaces, 20: 321-325.

Bochu, W., Xin, C., Zhen, W., Qizhong, F., Hao, Z., Liang, R., 2003. Biological effect of sound field stimulation on paddy rice seeds. Colloids and Surfaces B: Biointerfaces 32, 29-34.

Buchalo, A. S., Nevo, E., Wasser, S. P., Oren, A., Molitoris, H. P. 1998. Fungal life in the extremely hypersaline water of the Dead Sea: First records. Proceedings of the Royal Society B: Biological Sciences, 265: 1461-1465.

Cai, W., He, H., Zhu, S., Wang, N., 2014. Biological effect of audible sound control on mung bean (Vigna radiate) Sprout. BioMed Research International, Article ID 931740, 1-6.

Cao, S., Hu, Z., Pang, B., Wang, H., Xie, H., Wu, F., 2010. Effect of ultrasound treatment on fruit decay and quality maintenance in strawberry after harvest. Food Control, 21(4): 529-532.

Carlson, D., 2013. Sonic bloom organic farming made easy! The best organic fertilizer in the world. http://www.relfe.com/sonic bloom.html.

Chen $Y$, Jiang $Y M$, Yang $S Y$, Yang $E$, Yang $B$, Prasad K N., 2012. Effects of ultrasonic treatment on pericarp browning of postharvest litchi fruit. Journal of Food Biochemistry, 36 (5): 613-620.

Chen, Z., and C. Zhu., 2011. Combined effects of aqueous chlorine dioxide and ultrasonic treatments on postharvest storage quality of plum fruit (Prunus salicina L.). Postharvest Biology and Technology, 61: 117-123.

Chivukula, V., Ramaswamy, S., 2014. Effect of different types of music on Rosa chinensis plants. International Journal of Environmental Science and Development, 5 (5): 431-434.

Chowdhury, M. E., Lim, H., Bae, H. 2014. Update on the effects of sound wave on plants. Research in Plant Disease, 20 (1): 1-7.

Creath K., Schwartz G. E., 2004. Measuring effects of music, noise, and healing energy using a seed germination bioassay. The Journal of Alternative and Complementary Medicine, 10 (1): 113-122.

Cruz, R. M. S., Vieira, M. C., Silva, C. L. M., 2006. Effect of heat and thermosonication treatments on peroxidase inactivation kinetics in watercress (Nasturtium officinale). Journal of Food Engineering, 72(1): 8-15.

D'Amico, D.J., Silk, T.M., Wu, J., Guo, M., 2006. Inactivation of microorganisms in milk and apple cider treated with ultrasound. Journal of Food Protection, 69 (3): 556563. 
Depamphilis M L. 2003. Review the 'ORC cycle': a novel pathway for regulating eukaryotic DNA replication. Gene, 310: 1-15.

Dikilitas M, Karakas S. 2014. Crop plants under saline-adapted fungal pathogens: An Overview. In Emerging Technologies and Management of Crop Stress Tolerance, Volume II A sustainable Approach, London, Sydney, San Francisco, Elsevier Academic Press, pp. 173-185.

Dikilitas, M., Collins, A.R., Kocyigit, A., El Yamani, N., Karakas, S., 2015. DNA damage in potato plants exposed to high level of $\mathrm{NaCl}$ stress. Frontiers in Genetics, Conference Abstract: ICAW 2015 - 11th International Comet Assay Workshop. doi: 10.3389/conf.fgene.2015.01.00066.

Dolatowski, Z.J., Stadnik, J., Stasiak, D., 2007. Applications of ultrasound in food technology. Acta Scientiarum Polonorum Technologia Alimentaria, 6 (3): 89-99.

Earnshaw, R.G., Appleyard, J., Hurst, R.M., 1995. Understanding physical inactivation processes: Combined preservation opportunities using heat, ultrasound and pressure. International Journal of Food Microbiology, 28: 197-219.

Ekici, N., Dane, F. L., Madedova, I. M., Huseyinov, M., 2007. The effects of different musical elements on root growth and mitosis in onion (Allium cepa root apical meristem musical and biological experimental study). Asian Journal of Plant Sciences, 6: 369-373.

Elizaquivel, P., Sanchez, G., Selma, M.V., Aznar, R., 2012. Application of propidum monoazide-qPCR to evaluate the ultrasonic inactivation of Escherichia coli 0157: H7 in fresh-cut vegetable wash water. Food Microbiology, 30: 316-320.

Ercan, S. S., Soysal, C., 2011. Effect of ultrasound and temperature on tomato peroxidase. Ultrasonics Sonochemistry, 18(2), 686-695.

Fava, J., Hodara, K., Nieto, A., Guerrero, S., Alzamora, S. M., Castro, M. A., 2011. Structure (micro, ultra, nano), color and mechanical properties of Vitis labrusca $\mathrm{L}$. (grape berry) fruits treated by hydrogen peroxide, UV-C irradiation and ultrasound. Food Research International, 44 (9): 594595.

Fellows, P., 2000. Food Processing Technology: Principles and Practice, 2nd ed. CRC Press, New York.
Forghani, F., Oh, D. H., 2013. Hurdle enhancement of slightly acidic electrolyzed water antimicrobial efficacy on Chinese cabbage, lettuce, sesame leaf and spinach using ultrasonication and water wash. Food Microbiology, 36 (1): 40-49.

Gabaldon-Leyva, C. A., Quintero-Ramos, A., Barnard, J., Balandrán-Quintana, R. R., Talamás-Abbud, R. T., Jiménez-Castro, J., 2007. Effect of ultrasound on the mass transfer and physical changes in brine bell pepper at different temperature. Journal of Food Engineering, 81: 374-379.

Gabriel, A., 2012. Microbial inactivation in cloudy apple juice by multi-frequency Dynashock power ultrasound. Ultrasonics Sonochemistry, 19 (2): 346-351.

Gagliano, M., Stefano, M., Daniel, R., 2012. Towards understanding plant bioacoustics. Trends in Plant Science, 17: 323-325.

Galston, A.W., Slayman, C.L., 1979. The not-sosecret life of plants. American Scientist, 67: 337-344.

Golmohamadi, A., Möller, G., Powers, J., Nindo, C., 2013. Effect of ultrasound frequency on antioxidant activity, total phenolic and anthocyanin content of red raspberry puree. Ultrasonics Sonochemistry, 20(5): 1316-1323.

Hammack, T.S., Amaguana, R.M., Andrews, W.H., 2001. An improved method 355 for the recovery of Salmonella serovars from orange juice using universal 356 pre enrichment broth. Journal of Food Protection, 64: 659-663.

Hassanien, R. H., Hou, T., Li, Y., Li, B., 2014. Advances in effects of sound waves on plants. Journal of Integrative Agriculture, 13(2): 335-348.

Hou, T. Z., Li, B. M., Teng, G. H., Qi, L. R., Hou, K., 2010. Research and application progress of plant acoustic frequency technology. Journal of China Agricultural University, 1: 106-110.

Huang, T., Xu, C., Walker, K., West, P., Zhang, S., Weese, J., 2006. Decontamination efficacy of combined chlorine dioxide with ultrasonication on apples and lettuce. Journal of Food Science, 71 (4): 134-139.

Jiang, S., Huang, J., 2012. Effects of music acoustic frequency on greenhouse vegetable. Journal of Zhejiang University of Science and Technology, 24: 287-293. 
Johnson, K.A., Sistrunk, M.L., Polisensky, D.H., Braam, J., 1998. Arabidopsis thaliana responses to mechanical stimulation do not required ETR1 or EIN2. Plant Physiology, 116: 643-649.

Kadkhodaee, R., Povey, M.J.W., 2008. Ultrasonic inactivation of Bacillus $\alpha$-amylase I effect of gas content and emitting face of probe. Ultrasonics Sonochemistry, 15: 133-142.

Kenmotmsu, T., Ogawa, N., Kubota, R., Yoshida, K., Kagawa, Y., Watanabe, Y., Yoshikawa, Y., Yoshikawa, K. 2013. Double-Strand Breaks on a Genomic DNA Caused by Ultrasound: Evaluation by Single DNA Observation. International Symposium on Micro-Nanomechatronics and Human Science (MHS), Nagoya, Japan.

Kentish, S., Ashokkumar, M., 2011. The physical and chemical effects of ultrasound. In: Feng, H., Barbosa-Cánovas, G.V., Weiss, J. (Eds.), Ultrasound Technologies for Food and Bioprocessing. Springer, London, pp. 1-12.

Kim, H. J., Feng, H., Kushad, M. M., Fan, X., 2006. Effects of ultrasound, irradiation, and acidic electrolyzed water on germination of alfalfa and broccoli seeds and Escherichia coli 0157:H7. Journal of Food Science J Food Science, 71(6): 168-173.

Knorr, D., Zenker, M., Heinz, V., Lee, D., 2004. Applications and potential of ultrasonics in food processing. Trends in Food Science and Technology, 15: 261-266.

Ladeira, S. A., Cruz, E., Delatorre, A. B., Barbosa, J. B., Martins, M. L., 2015. Cellulase production by thermophilic Bacillus sp. SMIA-2 and its detergent compatibility. Electronic Journal of Biotechnology, 18(2): 110-115.

Leadley, C. E., Williams, A. 2006. Pulsed electric field processing, power ultrasound and other emerging technologies. In James $\mathrm{G}$. Brennan (Ed.), Food Processing Handbook. Weinheim: Wiley-Vch Verlag GmbH \& Co. KGaA.

Lee, H., Feng, H., 2011. Effect of power ultrasound on food quality. In: Feng, H., Barbosa-Cánovas, G.V., Weiss, J. (Eds.), Ultrasound Technologies for Food and Bioprocessing. Springer, London, pp. 559582.

Li P, Han T, Li L P, Wang Z M. 2007. Effect of ultrasound wave combined with calcium on reactive oxygen metabolism of postharvest peach. Scientia Silvae Sinicae, 43(8): 36-40.

Li, B., Wei, J. M., Wei, X. L., 2008. Effect of sound wave stress on antioxidant enzyme activities and lipid peroxidation of Dendrobium candidum. Colloids and Surfaces B: Biointerfaces, 63 (2): 269-275.

Lopez, P., Burgos, J., 1995. Peroxidase stability and reactivation after heat treatment and monothermosonication. Journal of Food Science, 60 (3): 451-455.

Lopez, P., Sala, F. J., De La Fuente, J. L., Condon, S., Raso, J., Burgos, J., 1994. Inactivation of peroxidase, lipoxygenase, and polyphenol oxidase by manothermosonication. Journal of Agricultural and Food Chemistry, 42: 252-256.

Mason T.J., 2003. Sonochemistry and sonoprocessing: the link, the trends and (probably) the future. Ultrasonics Sonochemistry, 10: 175-179.

Mawson, R., Gamage, M., Terefe, N. S., Knoerzer, $\mathrm{K} ., 2011$. Ultrasound in enzyme activation and inactivation. In H. Feng, G. V. BarbosaCánovas, \& J. Weiss (Eds.), Ultrasound technologies for food and bioprocessing, New York: Springer, pp. 369-404.

Meng, Q. W., Zhou, Q., Gao, Y., Zheng, S. J., Gao, Y., 2012. Effects of plant acoustic frequency technology on the growth traits, chlorophyll content and endogenous hormones of Lycopersicon esculentum. Hubei Agricultural Sciences, 51: 1591-1594.

Mothibe, K. J., Zhang, M., Nsor-Atindana, J., Wang, Y., 2011. Use of ultrasound pretreatment in drying of fruits: drying rates, quality attributes, and shelf life extension. Drying Technology, 29(14): 1611-1621.

Oyarzabal, O. A., Nogueira, M. C. L., Gombas, D.E., 2003. Survival of Escherichia coli 0157:H7, Listeria monocytogenes, and Salmonella in juice concentrates. Journal of Food Protection, 66: 1595-1598.

Piyasena, P., Mohareb, E., McKellar, R.C., 2003. Inactivation of microbes using ultrasound: A review. International Journal of Food Microbiology, 87 (3): 207-216.

Qi, L. R., Teng, G. H., Hou, T. Z., Zhu, B. Y., Liu, X., 2010. Influence of sound wave stimulation on the growth of strawberry in sunlight greenhouse. IFIP International Federation for Information Processing AICT, 317: 449454. 
Quan, K., 2011. Novel application of power ultrasonic spray. In: Feng, H., BarbosaCanovas, G., Weiss, J. (Eds.), Ultrasound Technologies for Food and Bioprocessing. Springer, London, pp. 535-544.

Raviyan, P., Zhang, Z., Feng, H., 2005. Ultrasonication for tomato pectinmethylesterase inactivation: effect of cavitation intensity and temperature on inactivation. Journal of Food Engineering, 70(2): 189-196.

Rivera, C.S., Venturini, M.E., Oria, R., Blanco, D., 2011. Selection of a decontamination treatment for fresh Tuber aestivum and Tuber melanosporum truffles packaged in modified atmospheres. Food Control, 22 (3-4): 626-632.

Sagong, H.G., Lee, S.Y., Chang, P.S., Heu, S., Ryu, S., Choi, Y.J., 2011. Combined effect of ultrasound and organic acids to reduce Escherichia coli 0157:H7, Salmonella typhimurium and Listeria monocytogenes on organic fresh lettuce. International Journal of Food Microbiology, 145 (1): 287-292.

Sao Jose, J.F.B., Vanetti, M.C.D., 2012. Effect of ultrasound and commercial sanitizers in removing natural contaminants and Salmonella enterica Typhimurium on cherry tomatoes. Food Control, 24 (1-2): 95-99.

Sarvaiya, N., Kothari, V., 2015. Effect of audible sound in form of music on microbial growth and production of certain important metabolites. Microbiology, 84 (2): 227-235.

Seymour, I.J., Burfoot, D., Smith, R.L., Cox, L.A., Lockwood, A., 2002. Ultrasound decontamination of minimally processed fruits and vegetables. International Journal of Food Science and Technology, 37: 547-557.

Shao, H. B., Li, B., Wang, B. C., Tang, K., Liang, Y., 2008. A study on differentially expressed gene screening of Chrysanthemum plants under sound stress. Comptes Rendus Biologies, 331: 329-333.

Takahashi, H., Suge, H. and Kato, T. 1991. Growth promotion by vibration at $50 \mathrm{~Hz}$ in rice and cucumber seedlings. Plant Cell Physiology, 32: 729-732.

Tiwari, B. K., O'Donnell, C. P. O., Patras, A., Brunton, N., Cullen, P. J., 2009. Stability of anthocyanins and ascorbic acid in sonicated strawberry juice during storage.
European Food Research Technology, 228 (5): 717-724.

Tiwari, B. K., Patras, A., Brunton, N., Cullen, P. J., O'Donnell, C. P., 2010. Effect of ultrasound processing on anthocyanins and color of red grape juice. Ultrasonics Sonochemistry, 17 (3): 598-604.

Uchida, A. Yamamoto, K. T., 2002. Effects of mechanical vibration on seed germination of Arabidopsis thaliana (L) Heynh. Plant Cell Physiology, 43: 647-651.

Valero, M., Recrosio,N., Saura, D., Munoz,N.,Marti,N., Lizama, V., 2007. Effects of ultrasonic treatments in orange juice processing. Journal of Food Engineering, 80: 509-516.

Vanol, D., Vaidya, R., 2014. Effect of types of sound (music and noise) and varying frequency on growth of guar or cluster bean (Cyamopsis tetragonoloba) seed germination and growth of plants. Quest, 2 (3): 9-14.

Wang B C ,Chen X, Wang Z, Fu Q Z , Zhou H , Ran L. 2003. Biological effect of sound field stimulation on paddy rice seeds. Colloids and Surfaces B: Biointerfaces, 32: 29-34.

Wang, Y., Hu, Y., Wang, J., Liu, Z., Yang, G., Geng, G., 2011. Ultrasound-assisted solvent extraction of swainsonine from Oxytropis ochrocephala Bunge. Journal of Medicinal Plants Research, 5 (6): 890-894.

Weinberger P, Measures M., 1979. Effects of the intensity of audible sound on the growth and development of Rideau winter wheat. Canadian Journal of Botany, 57: 10361039.

Weiss, J., Gulseren, I., Kjartansson, G., 2011. Physicochemical effects of high intensity ultrasonication on food proteins and carbohydrates. In: Zhang, H., BarbosaCanovas, G.V., Balasubramaniam, V.M., Dunne, C.P., Farkas, D.F., Yuan, J.T.C. (Eds.), Nonthermal Processing Technologies for Foods. Wiley, UK, pp. 109-134.

Xiaocheng, Y., Bochu, W., Chuanren, D. and Yi, J. 2003. Effects of sound stimulation on ATP content of Actinidia chinensis callus. Journal of Chinese Biotechnology, 23: 9597.

Xiujuan, W., Bochu, W., Yi, J., Chuanren, D., Sakanishi, A., 2003. Effect of sound wave on the synthesis of nucleic acid and protein in chrysanthemum. Colloids and Surfaces B: Biointerfaces, 29: 99-102. 
Yang X C, Wang B C, Ye M., 2004. Effects of different sound intensities on root development of Actinidia chinese plantlet. Chinese Journal of Applied \& Environmental Biology, 10: 274-276.

Yang, H., Swem, B. L., Li, Y., 2003. The effect of $\mathrm{pH}$ on inactivation of pathogenic bacteria on fresh-cut lettuce by dipping treatment with electrolyzed water. Journal of Food Protection, 68: 1013-1017.

Yang, X. C., Wang, B. C., Duan, C. R., 2003. Effects of sound stimulation on energy metabolism of Actinidia chinensis callus. Colloids and Surfaces B: Biointerfaces, 30: 67-72.

Yang, Z.F., Cao, S.F., Cai, Y.T., Zheng, Y.H., 2011. Combination of salicylic acid and ultrasound to control postharvest blue mold caused by Penicillium expansum in peach fruit. Innovative Food Science and Emerging Technologies, 12: 310-314.

Yi, J., Bochu, W., Xiujuan, W., Chuanren, D. and Xiaocheng, Y., 2003. Effect of sound stimulation on roots growth and plasmalemma H+-ATPase activity of chrysanthemum (Gerbera jamesonii). Colloids and Surfaces B: Biointerfaces 27: 65-69.

Yiyao, L., Bochu, W., Xuefeng, L., Chuanren, D., Sakanishi, A., 2002. Effects of sound field on the growth of Chrysanthemum callus, Colloids and Surfaces B: Biointerfaces 24, 321-326.

Zhang, J., 2012. Application progress of plant audio control technology in modern agriculture. Ningxia Journal of Agriculture and Forestry Science and Technology, 53, 80-81. 